\title{
EFFECT OF ACIDOSIS AND ALKALOSIS UPON CAPACITY FOR WORK
}

\author{
By H. DENNIG,' J. H.'TALBOTT, H. T. EDWARDS AND D. B. DILL
}

(From the Fatigue Laboratory, Morgan Hall, Harvard University, Boston)

(Received for publication September 16, 1930)

The composition of arterial blood in exercise varies with the intensity of the exertion. In moderate work, percentage saturation of hemoglobin, alkaline reserve and hydrogen ion concentration remain constant or nearly so while the proportion of hemoglobin in blood and of protein in serum increase from 5 to 10 per cent. When exercise is carried on to exhaustion there is little or no further increase in concentration of blood proteins but lactic acid concentration may increase to $11 \mathrm{~m} . \mathrm{Eq}$. per liter and carbonic acid capacity ${ }^{2}$ may decrease in nearly reciprocal fashion. There may be a decrease in arterial $\mathrm{pH}_{\mathrm{s}}$ of 0.3 which means a liberation of base bound by protein. Work cannot be continued if lactic acid concentration much exceeds $10 \mathrm{~m}$.Eq. per liter of blood.

In circulatory diseases the description cannot be given in such precise fashion. The capacity for oxygen transport to the tissues is diminished, the composition of the blood in rest is variable, and it has been suggested by Eppinger and his associates and by Pilcher, Clark and Harrison (1930) that the buffering power of the blood and tissues is diminished in congestive heart failure.

In view of the complications associated with exercising a sick man we have established acidosis in a normal man (H. D.) by ammonium chloride administration and have studied his performance while normal while in acidosis and while in the alkalosis subsequent to withdrawing ammonium chloride. The composition of urine and the respiratory changes in rest have been described by Dennig, Dill and Talbott (1929).

1 Privatdocent in the Medical Clinic, Heidelberg.

2 The expression carbonic acid capacity denotes the carbonic acid content of oxygenated blood equilibrated at $37.5^{\circ}$ with $\mathrm{CO}_{2}$ at a partial pressure of $40 \mathrm{~mm}$. This quantity is also referred to as $T_{40}$. 
TABLE 1

Observations on equilibrated blood

\begin{tabular}{|c|c|c|c|c|c|c|c|}
\hline $\begin{array}{c}\text { Experi- } \\
\text { ment } \\
\text { number }\end{array}$ & Date & Condition & $\begin{array}{c}\mathrm{HbO}_{2} \\
\text { capacity }\end{array}$ & $\mathrm{pCO}_{2}$ & Tota & $\mathrm{CO}_{2}$ & $\begin{array}{l}\text { Calcu- } \\
\text { lated }\end{array}$ \\
\hline & & & $\begin{array}{c}\text { m.Eq. } \\
\text { per liler }\end{array}$ & mm.Hg. & $\begin{array}{l}\text { m.Eq. per } \\
\text { liter blood }\end{array}$ & $\begin{array}{l}\text { m.Eq. per } \\
\text { liter serum }\end{array}$ & $\mathrm{pH}_{s}$ \\
\hline 1 & May 28 & $\begin{array}{l}\text { Acidosis, } \\
\text { Rest }\end{array}$ & 9.11 & 41.6 & 17.9 & 20.7 & 7.28 \\
\hline & & & & 74.8 & 22.5 & 25.7 & 7.11 \\
\hline & & Work & 9.64 & 30.8 & 11.5 & 13.6 & 7.22 \\
\hline & & & & 68.0 & 17.4 & $19.8^{*}$ & 7.02 \\
\hline 2 & June 6 & Alkalosis, & & & & & \\
\hline & & Rest & 7.76 & 43.6 & 25.9 & 31.2 & 7.45 \\
\hline & & & & 74.9 & 31.5 & $37.2^{*}$ & 7.28 \\
\hline & & Work & 8.70 & 43.2 & 23.2 & 28.4 & 7.41 \\
\hline & & & & 74.4 & 28.4 & $34.0^{*}$ & 7.24 \\
\hline 3 & June 22 & Normal, & & & & & \\
\hline & & Rest & 9.02 & 36.3 & 19.9 & 24.5 & 7.42 \\
\hline & & & & 72.2 & 26.4 & $31.4^{*}$ & 7.22 \\
\hline & & Work & 9.56 & 33.9 & 17.8 & 21.8 & 7.40 \\
\hline & & & & 70.1 & 24.7 & $29.1^{*}$ & 7.20 \\
\hline 4 & September 27 & Normal, & & & & & \\
\hline & & Rest & 9.06 & 46.7 & 22.6 & 26.5 & 7.34 \\
\hline & & & & 79.2 & 27.5 & $31.7^{*}$ & 7.18 \\
\hline & & Work & 10.50 & 39.4 & 16.6 & 20.2 & 7.29 \\
\hline & & & & 98.2 & 25.3 & $29.4^{*}$ & 7.04 \\
\hline 5 & September 29 & Acidosis, & & & & & \\
\hline & & Rest & 10.05 & 26.9 & 9.68 & 11.3 & 7.20 \\
\hline & & & & 59.9 & 15.1 & $17.1^{*}$ & 7.02 \\
\hline & & Work & 10.80 & 31.1 & 8.74 & 9.84 & 7.07 \\
\hline & & & & 68.8 & 14.2 & $15.5^{*}$ & 6.90 \\
\hline 6 & October 1 & Alkalosis, & & & & & \\
\hline & & Rest & 7.86 & 29.6 & 22.5 & 27.9 & 7.57 \\
\hline & & & & 64.5 & 29.7 & $35.6^{*}$ & 7.33 \\
\hline & & Work & 8.75 & 34.4 & 20.1 & 24.2 & 7.44 \\
\hline & & & & 70.2 & 26.7 & $31.2^{*}$ & 7.23 \\
\hline
\end{tabular}

* The indicated values were not determined experimentally but were calculated from the line charts developed by Van Slyke and Sendroy (1928). 
The essential observations on oxygenated blood equilibrated with carbon dioxide are given in chronological order in table 1. It will be noted that two sets of experiments were carried out with an intervening period of about three months. The details with regard to diet and ammonium chloride intake in the former set of experiments will be found in the paper referred to above; in the second set of experiments the same diet was followed and 15 grams of ammonium chloride were taken on two days only, September 27 and 28. After the acidosis experiment on the 29th and again on the 30th, 10 grams of sodium bicarbonate were taken. The resulting alkalosis was so severe that slight tetanic cramps were experienced the night of September 30-October 1 . These had disappeared by the time the alkalosis experiment was begun on October 1 .

The exercise in the first set of experiments consisted in running at the rate of $7.4 \mathrm{~km}$. per hour for 15 minutes. The subject had had little experience on the treadmill at this time and his performances were not skillful. During September he had 12 practice runs at $9.3 \mathrm{~km}$. per hour and succeeded finally in running at this speed with a fairly constant day-to-day performance and with about the same oxygen consumption as at the slower rate. On the basis of these experiments, but particularly on the last set with the subject in better training and running at a faster speed, it is possible to make an estimate of the effects of acidosis and of alkalosis upon the performance of a given task.

The lactic acid which accumulates during exhausting work can be neutralized by three mechanisms working together. ${ }^{3}$ The simplest is by the reaction

$$
\mathrm{BHCO}_{3}+\text { Lactic acid } \rightarrow \mathrm{B}(\text { lactate })+\mathrm{H}_{2} \mathrm{CO}_{3}
$$

In order that this mechanism may function it is necessary for the lung to put out carbonic acid faster than it is produced by oxidative processes, and this in fact is what occurs, the result being an apparent increase in respiratory quotient. It is physiologically impossible to increase alveolar ventilation enough in the extreme acidosis of exhaus-

${ }^{3}$ The possible buffering effect of phosphocreatine has been neglected in the absence of evidence that hydrolysis of this substance is quantitatively important in normal muscular activity. 
tion to maintain the ratio $\frac{\mathrm{H}_{2} \mathrm{CO}_{3}}{\mathrm{BHCO}_{3}}$ at its resting level and the result is that, although the reaction of arterial blood in moderate work may be the same as during rest, in exhaustion there is always an increase

TABLE 2

Buffer value calculations

\begin{tabular}{|c|c|c|c|c|c|}
\hline $\begin{array}{l}\text { Experiment } \\
\text { number }\end{array}$ & Condition & $\triangle \mathrm{BHCO}_{3}$ & Protein & $\frac{-\Delta \mathrm{BHCO}_{3} \times 10^{3}}{(\Delta \mathrm{pH}) \text { (protein) }}$ & $T_{40^{*}}$ \\
\hline \multirow{3}{*}{1} & & $\begin{array}{l}\text { m.Eq. per } \\
\text { liter blood }\end{array}$ & $\begin{array}{l}\text { grams per } \\
\text { liter blood }\end{array}$ & & $\begin{array}{l}\text { m.Eq. per } \\
\text { liter blood }\end{array}$ \\
\hline & Acidosis, & 36 & 100 & 106 & 176 \\
\hline & Wórk & 4.8 & 207 & 116 & 13.1 \\
\hline \multirow[t]{2}{*}{2} & $\begin{array}{l}\text { Alkalosis, } \\
\text { Rest }\end{array}$ & 4.7 & 180 & 153 & 25.2 \\
\hline & Work & 4.3 & 193 & 131 & 22.5 \\
\hline \multirow[t]{2}{*}{3} & $\begin{array}{c}\text { Normal, } \\
\text { Rest }\end{array}$ & 5.5 & 198 & 139 & 20.7 \\
\hline & Work & 5.9 & 206 & 143 & 19.1 \\
\hline \multirow[t]{2}{*}{4} & $\begin{array}{c}\text { Normal, } \\
\text { Rest }\end{array}$ & 4.0 & 198 & 126 & 21.5 \\
\hline & Work & 7.0 & 220 & 127 & 16.6 \\
\hline \multirow[t]{2}{*}{5} & $\begin{array}{l}\text { Acidosis, } \\
\text { Rest }\end{array}$ & 4.5 & 213 & 117 & 12.1 \\
\hline & Work & 4.4 & 224 & 115 & 10.2 \\
\hline \multirow[t]{2}{*}{6} & $\begin{array}{l}\text { Alkalosis, } \\
\text { Rest }\end{array}$ & 6.1 & 181 & 140 & 25.2 \\
\hline & Work & 5.6 & 194 & 137 & 21.2 \\
\hline
\end{tabular}

* The expression carbonic acid capacity denotes the carbonic acid content of oxygenated blood equilibrated at $37.5^{\circ}$ with $\mathrm{CO}_{2}$ at a partial pressure of $40 \mathrm{~mm}$. This quantity is also referred to as $T_{\mathbf{4 0}}$.

in acidity. This brings into action the third mechanism, by means of which base bound by protein is set free to neutralize lactic acid:

$$
\mathrm{BP}+\text { Lactic acid } \rightarrow \mathrm{B} \text { (lactate) }+\mathrm{HP}
$$

To what extent are these mechanisms modified by the conditions in our experiments? Assuming that parallel changes take place in 
blood and in muscles insofar as the principal anions are concerned, it is possible to estimate the effect of variation in carbonic acid capacity upon the buffer value of the protein-bicarbonate system. For this

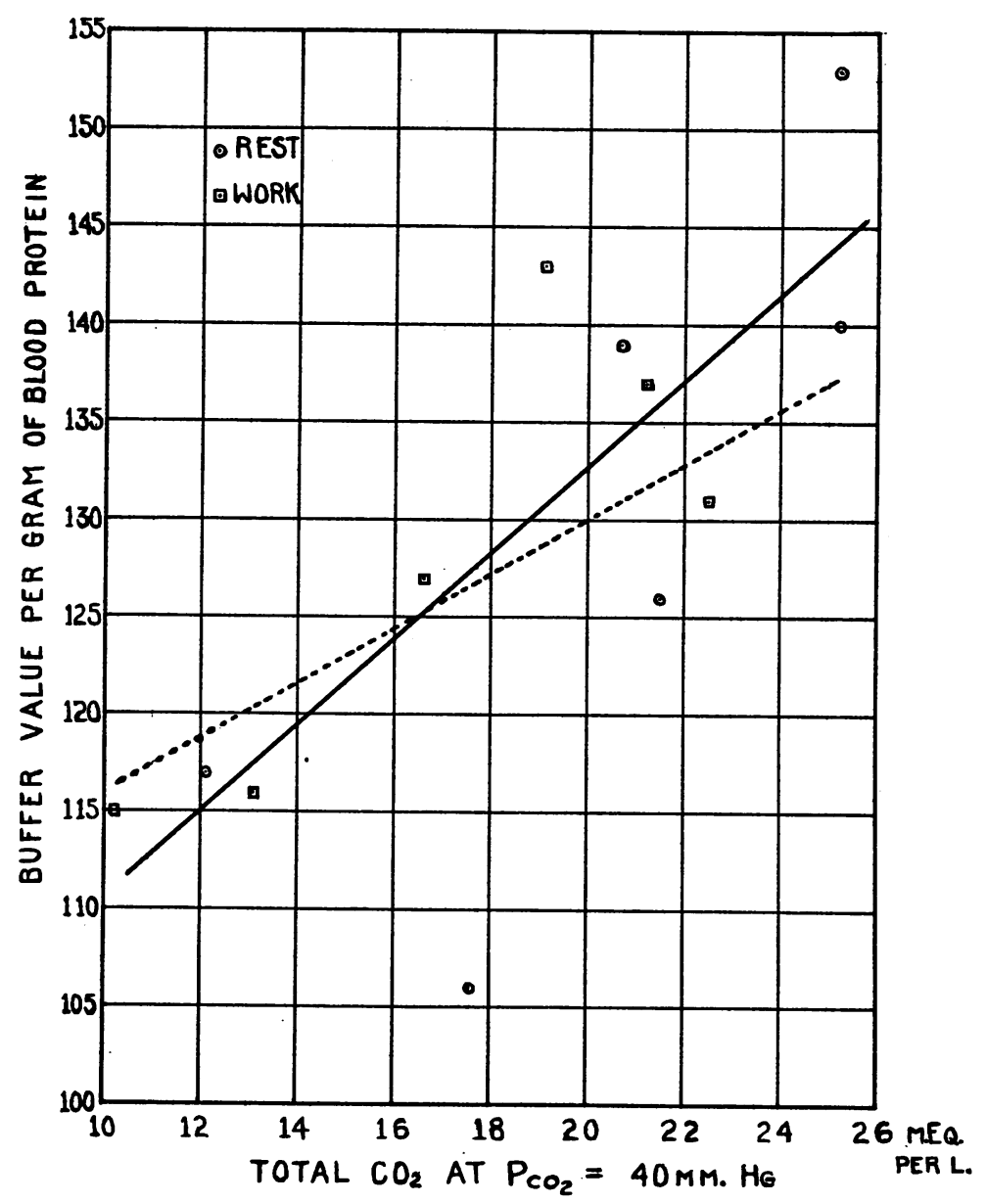

FIG. 1

purpose the calculations shown in table 2 have been made. Column 3 has been derived in an obvious manner from the observations on equilibrated blood given in the preceding table and from the solubility determinations for carbon dioxide in serum and cells made by Van 
Slyke, Sendroy, Hastings and Neill (1928). A measure of buffer value of blood as defined by Van Slyke may be obtained by dividing $\triangle \mathrm{BHCO}_{3}$ by values for $\Delta \mathrm{pH}_{s}$ derived from table 1 . These buffer values are related in a linear fashion to blood protein concentration and in order to eliminate this variable the buffer values per unit of blood protein have been calculated as appears in column $5 .{ }^{4}$

It is now possible to determine the relation between buffer value and carbonic acid capacity. The last column in this table gives the total carbonic acid content of each specimen of blood at a carbonic acid pressure of $40 \mathrm{~mm}$. Figure 1 illustrates the relation between the variables total carbonic acid at $p^{2} \mathrm{CO}_{2}=40 \mathrm{~mm}$. and buffer value per unit of blood protein. The points show considerable fluctuation partly due, no doubt, to experimental errors and perhaps also to failure to take into account other variables. (Thus comparison is made over the physiological range but not over the same range in $\mathrm{pH}_{8 .}$ )

An equation showing the straight line trend of these points has been derived according to the Pearson formula,

$$
y=R x-R x_{m}+y_{m}
$$

in which $x_{m}=$ mean value of $x$

$$
\begin{aligned}
y_{n} & =\text { mean value of } y \\
R & =\frac{n(\Sigma x y)-\Sigma x \Sigma y}{n \Sigma x^{2}-(\Sigma x)^{2}} \\
n & =\text { number of observations }
\end{aligned}
$$

If $y=$ buffer value and $x=$ carbonic acid capacity, one derives an equation in which the experimental errors are assumed to lie principally in the determination of $y$ and of course this assumption is correct, for $x$ can be determined precisely. The resulting relationship is

$$
\text { Buffer value }=2.1 \text { (carbonic acid capacity) }+89
$$

The solid line shown on figure 1 corresponds to this equation. The fact that the regression coefficient of this equation is $2.1 \pm 0.57$ indicates that the slope is only roughly defined.

4 There is an error involved in this calculation in the assumption that serum protein and hemoglobin have the same buffer value per unit weight but for our present purposes this error is negligible. 
It is interesting to see to what extent these results are in accord with the empirical description of carbonic acid dissociation curves given by Henderson and associates (1930). To make such a comparison we have prepared table 3 . This shows for each experiment the observed $\Delta \mathrm{CO}_{2}(60-30)$ and the values for the same variable as estimated from figure 3 of the paper just referred to. The last column is derived as indicated and is a measure of the change in buffer value of blood proteins with $T_{40}$ as implied by this empirical chart. The mean value of $R$ is 1.00 but the positive and negative errors are so distributed

TABLE 3

Buffer values from the empirical description of $\mathrm{CO}_{2}$ curves (Henderson et al.)

\begin{tabular}{|c|c|c|c|c|}
\hline \multirow{2}{*}{$T_{40}$} & \multicolumn{3}{|c|}{$\Delta \mathrm{CO}_{2}(60-80)$} & \multirow{2}{*}{$\frac{-\Delta \mathrm{BHCO}_{2} \times 10^{3}}{(\Delta \mathrm{pH})(\text { protein) }} \times \frac{1}{R}$} \\
\hline & Experimental & Calculated & $R=\frac{\text { Experimental }}{\text { Calculated }}$ & \\
\hline m.Eg. per liter & m.Eq. per liter & m.Eq. per liter & & \\
\hline 17.6 & 4.9 & 5.50 & 0.89 & 119 \\
\hline 13.1 & 5.0 & 5.09 & 0.98 & 118 \\
\hline 25.2 & 6.5 & 5.96 & 1.09 & 141 \\
\hline 22.5 & 6.0 & 6.00 & 1.00 & 131 \\
\hline 20.7 & 6.1 & 5.87 & 1.04 & 134 \\
\hline 19.1 & 6.1 & 5.87 & 1.04 & 137 \\
\hline 21.5 & 5.7 & 6.00 & 0.95 & 133 \\
\hline 16.6 & 5.5 & 5.82 & 0.95 & 134 \\
\hline 12.1 & 4.7 & 4.90 & 0.96 & 122 \\
\hline 10.2 & 4.4 & 4.57 & 0.99 & 116 \\
\hline 25.2 & 6.4 & 6.00 & 1.07 & 131 \\
\hline 21.2 & 6.0 & 5.83 & 1.03 & 133 \\
\hline
\end{tabular}

that when one calculates the trend of these points as before the equation comes out

Buffer value $=1.4$ (carbonic acid capacity) +102

The broken line in the figure corresponds to this equation. It appears, from our experimental observations, that when the carbonic acid capacity is reduced by one-half the buffer value of blood proteins is reduced by one-sixth. On the basis of the Henderson chart the reduction is one-ninth.

The empirical chart just referred to is based wholly on experimental 
observations on blood in this laboratory. A similar chart was prepared from previous knowledge of the properties of the components of the system (fig. 5 in the same paper). One of the assumptions was expressed by the relation developed by Van Slyke

$$
\mathrm{BHbO}_{2}=3.6 \mathrm{Hb}\left(\mathrm{pH}_{c}-6.41\right)
$$

We find that it is now necessary in order to express the facts more accurately to use the equation

$$
\mathrm{BHbO}_{2}=\mathrm{Hb}\left(9.75 \mathrm{pH}_{8}-0.5\left(\mathrm{pH}_{8}\right)^{2}+\mathrm{n}\right)
$$

While there must remain some doubt regarding the magnitude of this effect, its reality is obvious. It was in fact suggested by Dill, Bock, Lawrence, Talbott and Henderson (1929). Figure 8 in that paper shows blood bicarbonate as a function of $\mathrm{pH}_{8}$ in various bloods. No account was taken of variation in protein concentration and hence the slopes of the different curves are variable on that account as well as on account of variation in carbonic acid capacity. However, there is no question about the change in slope with $\mathrm{pH}_{s}$ in diabetic coma. A tangent is drawn to the curve of T. F. B. in the physiological range. Its slope is very different from that in normal blood. The buffer value calculated as above, taking into account blood protein concentration, comes out as 30 , one-fourth of the normal value.

It was pointed out in that paper that such a result should not have been wholly unexpected. Thus if one extrapolates the straight line corresponding to horse blood, as determined by Van Slyke, it intersects the line $\left(\mathrm{BHCO}_{3}\right)_{b}=\mathrm{O}$ at a $\mathrm{pH}_{8}$ value of 7.94 . This does not happen in normal blood, indicating again that as one reaches low values of $\left(\mathrm{BHCO}_{3}\right)_{b}$ buffer value decreases.

There remains the question of hydrogen ion concentration in its relation to breathing and the liberation of base from protein. The observations on oxygen consumption and on ventilation are given in table 4. Samples of alveolar air were obtained and from the carbon dioxide pressure in these samples and the carbonic acid dissociation curves described in table 1 it was possible to derive the values for $\mathrm{pH}$ of arterial serum and for total $\mathrm{CO}_{2}$ content of arterial blood which are shown in table 4 . The same table contains the values for lactate content of blood. 
The values for oxygen consumption in work given in this table show greater variation from day to day than that observed in an athlete performing a fixed task. This may be in part related to the physical condition of the runner. On certain days, particularly on May 28, September 29, and October 1, the subject was in some distress before work began and hence ran with less perfect nervous coordination than

TABLE 4

Respiratory changes and composition of arterial blood

\begin{tabular}{|c|c|c|c|c|c|c|}
\hline & $\mid \begin{array}{c}\text { Experi- } \\
\text { ment 1 }\end{array}$ & \begin{tabular}{|l|} 
Experi- \\
ment 2
\end{tabular} \mid & $\mid \begin{array}{l}\text { Experi- } \\
\text { ment 3 }\end{array}$ & $\mid \begin{array}{l}\text { Experi- } \\
\text { ment 4 }\end{array}$ & $\left|\begin{array}{l}\text { Experi- } \\
\text { ment 5 }\end{array}\right|$ & \begin{tabular}{|l} 
Experi- \\
ment 6
\end{tabular} \\
\hline & $\begin{array}{c}\text { Acido- } \\
\text { sis }\end{array}$ & $\begin{array}{l}\text { Alka- } \\
\text { losis }\end{array}$ & $\begin{array}{l}\text { Nor- } \\
\text { mal }\end{array}$ & $\begin{array}{c}\text { Nor- } \\
\text { mal }\end{array}$ & $\begin{array}{c}\text { Acido- } \\
\text { sis }\end{array}$ & $\begin{array}{l}\text { Alka- } \\
\text { losis }\end{array}$ \\
\hline \multicolumn{7}{|l|}{ Oxygen used, liters per minute: } \\
\hline Work. & 2.69 & 1.96 & 2.19 & 2.36 & 2.75 & 2.52 \\
\hline \multicolumn{7}{|l|}{ Ventilation, liters per minute: } \\
\hline Rest............... & 6.4 & 4.8 & 5.4 & 5.4 & 8.5 & 5.6 \\
\hline rk............ & 82 & 46 & 54 & 48 & 80 & 51 \\
\hline Work $\div$ Rest. . & 13 & 10 & 10 & 9 & & 9 \\
\hline \multicolumn{7}{|l|}{$\mathrm{pH}_{8}:$} \\
\hline Rest. & 7.38 & 7.46 & 7.39 & .7 .41 & 7.21 & 7.47 \\
\hline Work. & 7.25 & 7.43 & 7.38 & 7.30 & 7.09 & 7.39 \\
\hline$\Delta \ldots$ & -0.13 & -0.03 & -0.01 & -0.11 & -0.12 & -0.08 \\
\hline \multicolumn{7}{|l|}{$\left(\text { Total } \mathrm{CO}_{2}\right)_{b}$, m.Eq. per liter: } \\
\hline Rest. & 15.6 & 25.7 & 20.6 & 21.2 & 9.6 & 25.2 \\
\hline Work. . & 10.8 & 23.0 & 18.2 & 16.5 & 8.1 & 21.3 \\
\hline$\Delta \ldots \ldots$ & -4.8 & -2.7 & -2.4 & -4.7 & -1.5 & -3.9 \\
\hline \multicolumn{7}{|l|}{ (Lactate) $_{b}, m . E q$. per liter: } \\
\hline & 0.9 & 0.8 & 0.9 & 1.3 & 0.7 & 1.4 \\
\hline Work. . & 4.6 & 3.2 & 2.5 & 5.0 & 2.7 & 4.5 \\
\hline$\Delta \ldots$ & $|+3.7|$ & $|+2.4|$ & $|+1.6|$ & $|+3.7|$ & $+2.0 \mid$ & |+3.1 \\
\hline
\end{tabular}

at other times. Some such explanation is more probable than one involving difference in intrinsic processes.

The limiting value for total ventilation in non-athletic subjects usually lies between 75 and 100 liters per minute and it is probable that the subject had reached his maximum rate on May 28 and September 29. The alveolar carbon dioxide pressure in work on September 29 
was $28 \mathrm{~mm}$. and this probably can be taken as near the physiological limit for, in this case, the $\mathrm{pH}$ of arterial serum was 7.09 and that of venous serum must have been about 6.95. These reactions are even more acid than those usually found in diabetic coma.

TABLE 5

Limiting values for $T_{10}$ and arterial $p H_{s}$ in normal men

\begin{tabular}{|c|c|c|c|c|}
\hline Subject & Exercise & Lactic acid & $T_{40}$ & $\begin{array}{l}\mathrm{pH} \text { of arterial } \\
\text { serum* }\end{array}$ \\
\hline & & m.Eq. per liter & m.Eq. per liter & \\
\hline J. W.. & Rowing & 9.8 & 12.1 & 7.11 \\
\hline J. R. . & Rowing & 11.0 & 10.4 & 7.02 \\
\hline M. H... & Running & 9.6 & 13.5 & 7.16 \\
\hline J. H. T.. & Running & 8.4 & 12.7 & $7.14 \pm 0.04$ \\
\hline A. V. B.... & Running & 9.4 & 11.7 & $7.08 \pm 0.04$ \\
\hline D. B. D.... & Running & 10.5 & 13.2 & 7.14 \\
\hline
\end{tabular}

* The values for $\mathrm{pH}$ of arterial serum were calculated from the dissociation curve of true plasma of oxygenated blood and from the carbon dioxide pressure of samples of alveolar air, assuming that such samples represent air in complete equilibrium with arterial blood.

TABLE 6

Effect of acidosis and alkalosis on capacity of blood for neutralizing lactic acid

\begin{tabular}{|c|c|c|c|c|c|c|}
\hline & $\begin{array}{l}\text { Experi- } \\
\text { ment } 1\end{array}$ & $\begin{array}{l}\text { Experi- } \\
\text { ment } 2\end{array}$ & $\begin{array}{l}\text { Experi- } \\
\text { ment } 3\end{array}$ & $\begin{array}{l}\text { Experi- } \\
\text { ment } 4\end{array}$ & $\begin{array}{l}\text { Experi- } \\
\text { ment } 5\end{array} \mid$ & $\begin{array}{l}\text { Experi- } \\
\text { ment } 6\end{array}$ \\
\hline & Acidosis & Alkalosis & Normal & Normal & $\begin{array}{c}\text { Acido- } \\
\text { sis }\end{array}$ & Alkalosis \\
\hline 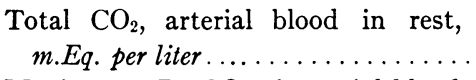 & 15.6 & 25.7 & 20.6 & 21.2 & 9.6 & 25.2 \\
\hline 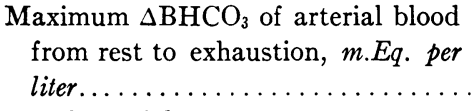 & -7.5 & -17.6 & -12.5 & -13.1 & -1.5 & -17.1 \\
\hline pH of arterial serum, rest........... & 7.38 & 7.46 & 7.39 & 7.41 & 7.21 & 7.47 \\
\hline 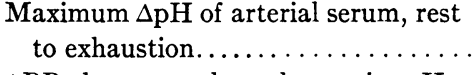 & -0.29 & -0.37 & -0.30 & -0.32 & -0.12 & -0.38 \\
\hline $\begin{array}{c}\Delta \mathrm{BP} \text { due to such a change in } \mathrm{pH} \\
m . \text { Eq. per liter. } \ldots \ldots \ldots \ldots \ldots \ldots\end{array}$ & -7.1 & -9.1 & -7.6 & -8.7 & -3.0 & -9.4 \\
\hline $\begin{array}{l}\text { Acid neutralizing capacity, - } \\
\quad\left(\Delta \mathrm{BHCO}_{3}+\Delta \mathrm{BP}\right), \text { m.Eq. per liter. }\end{array}$ & +14.6 & +26.7 & +20.1 & +21.8 & +4.5 & +26.5 \\
\hline
\end{tabular}

In various unpublished observations we have indirect evidence that the reaction reached in this experiment is near the limit for man starting from a normal state. Table 5 is a summary of six experiments in which men started from a normal state and pushed themselves to 
exhaustion with lactic acid concentrations of 9 to $11 \mathrm{~m} . \mathrm{Eq}$. per liter. Two subjects were oarsmen in good training and there was not a striking difference between the composition of their blood in exhaustion and that of the four untrained subjects. No experiments with a subject starting from a state of alkalosis have been carried out aside from the two on H.D. However, since the limiting values for $\mathrm{pH}$ and carbonic acid capacity reached during exhausting work are of the same order of magnitude whether one starts from a normal state or from a state of acidosis, it appears probable that the same is true starting from a state of alkalosis. We shall make this assumption tentatively and proceed to calculate the amount of acid which could have been neutralized per liter of blood between the observed values of $\mathrm{pH}_{s}$ and of carbonic acid content in rest and the assumed limiting values in exhaustion, viz., $\mathrm{pH}_{s}=7.09$ and total carbonic acid content of arterial blood $=8.1 \mathrm{~m}$.Eq. per liter. The calcuations by which table 6 is derived are made by a simple application of the data in the figure (solid line) and in tables 1, 2 and 4. The calculation in the first experiment may be shown for illustration:

Total $\mathrm{CO}_{2}$ of arterial blood in rest, m.Eq. per liter ............ 15.6

Minimum $\mathrm{CO}_{2}$ of arterial blood in exhaustion, m.Eq. per liter ......

$\Delta$ Total $\mathrm{CO}_{2}$ of arterial blood rest to exhaustion, m.E. per liter .... $\overline{-7.5}$

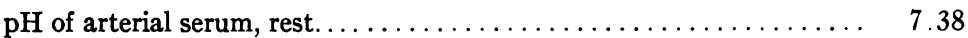

Minimum pH of arterial serum, exhaustion................. 7.09

$\Delta \mathrm{pH}$, rest to work. ............................ $\overline{-0.29}$

Blood protein in work, grams per liter.................. 207

Carbonic acid capacity in rest, $m . E q$. per liter............... 17.6

Carbonic acid capacity in exhaustion, $m . E q$. per liter........... 10.2

Mean carbonic acid capacity in work, $m . E q$. per liter ........... $\frac{13.9}{13.9}$

Corresponding protein buffer value....................... 0.119

$\Delta \mathrm{BP}=($ Buffer value $)\left(\Delta \mathrm{pH}_{s}\right)$ (Protein), m.Eq. per liter......... -7.1

Acid neutralizing capacity $=-\left(\Delta \mathrm{BHCO}_{3}+\Delta \mathrm{BP}\right)$, m.Eq. per liter... 14.6

It is necessary to emphasize that the neutralizing capacities shown in table 6 are for blood and that it is probable that the capacity of tissues, per unit weight, for neutralizing acid is less than that of blood. Thus the results of Fenn (1928) indicate that muscle has a flatter dissociation curve and a lower carbonic acid capacity than blood. However, it is quite probable that acidosis and alkalosis have parallel 
effects on blood and on tissues. Taking the maximum neutralizing capacity of normal blood in rest as 100 , the other values are as follows:

\begin{tabular}{|c|c|}
\hline Acidosis & Alkalosis \\
\hline dy compensated)..... 70 & $22 \ldots \ldots \ldots \ldots \ldots \ldots \ldots 127$ \\
\hline$\ldots \ldots 21$ & oer $1 \ldots \ldots$ \\
\hline
\end{tabular}

There is conclusive evidence that the capacity for oxygen debt is decreased when work is undertaken in ammonium chloride acidosis. On September 29, the subject was unable to run longer than 15 minutes although his lactic acid concentration was only $2 \mathrm{~m}$.Eq. per liter of blood. In other experiments he ran for 18 or 20 minutes, sometimes with much more lactic acid, and yet with less distress at the finish.

It appears from table 6 that a runner starting off in alkalosis can pile up a greater oxygen debt than when in his normal state. The work was not severe enough to give this hypothesis a rigid test but the problem has interesting possibilities and may be investigated further at a later time.

There is an ambiguity of considerable importance which awaits further investigation. The observed increases in lactic acid in Dennig's second acidosis experiment and in the six experiments summarized in table 5 are very much less than the estimated acid neutralizing capacities. There are no complete observations on the acid-base equilibrium in such a state of exhaustion and it would be unprofitable to seek for an explanation without such information.

There are obvious connections between these results and those obtained in heart disease. Clearly the capacity to accumulate an oxygen debt decreases with carbonic acid capacity because the amount of bicarbonate available for neutralizing lactic acid is decreased and at the same time the buffer value of proteins decreases with decrease in carbonic acid capacity. In heart disease there may be some additional modification of muscle proteins in respect to their buffer value as suggested by Pilcher, Clark and Harrison, but our studies contribute nothing to this queston. They have found evidence of some such change only when edema is present and it is possible that the phenomena they have observed are related in some way to modification of diffusion processes in the tissues by increase in intracellular fluid. 


\section{SUMMARY}

A study has been made of the effects of muscular activity on properties of the blood in three states: (1) normal; (2) acidotic due to ammonium chloride intake and (3) in a state of alkalosis subsequent to ammonium chloride intake.

The buffer value of blood proteins is reduced one-ninth or more with a decrease of one-half in carbonic acid capacity. Due to this effect as well as to decrease in carbonic acid capacity, the ability to neutralize lactic acid and hence to accumulate an oxygen debt is greatly curtailed when one begins exercise in a state of acidosis. Inferentially, the ability to accumulate an oxygen debt is increased by establishing a state of alkalosis before beginning exercise.

\section{BIBLIOGRAPHY}

Dennig, H., Dill, D. B., and Talbott, I. H., Arch. f. exp. Path. u. Pharm., 1929, cxliv, 297. Bilanzuntersuchung einer Salmiakazidose.

Dill, D. B., Bock, A. V., Lawrence, J. S., Talbott, J. H., and Henderson, L. J., J. Biol. Chem., 1929, lxxxi, 551. Blood as a Physicochemical System. VIII. Diabetic Coma.

Eppinger, H., Kisch, F., and Schwarz, H., Das Versagen des Kreislaufes. Berlin, 1927

Fenn, W. O., Am. J. Physiol., 1928, lxxxv, 207. The Carbon Dioxide Dissociation Curve of Nerve and Muscle.

Henderson, L. J., Bock, A. V., Dill, D. B., and Edwards, H. T., J. Biol. Chem., 1930, lxxxvii, 181. Blood as a Physicochemical System. IX. The Carbon Dioxide Dissociation Curves of Oxygenated Human Blood.

Pilcher, C., Clark, G., and Harrison, T. R., J. Clin. Invest., 1930, viii, 317. Studies in Congestive Heart Failure. III. The Buffering Power of the Blood and Tissues.

Van Slyke, D. D., Sendroy, Julius, Jr., Hastings, A. B., and Neill, J. M., J. Biol. Chem., 1928, lxxviii, 765. Studies of Gas and Electrolyte Equilibria in Blood. X. The Solubility of Carbon Dioxide at $38^{\circ}$ in Water, Salt Solution, Serum, and Blood Cells.

Van Slyke, D. D. and Sendroy, Julius, Jr., J. Biol. Chem., 1928, lxxix, 781. Studies of Gas and Electrolyte Equilibria in Blood. X. Line Charts for Graphic Calculations by the Henderson-Hasselbalch Equation, and for Calculating Plasma Carbon Dioxide Content from Whole Blood Content. 